\title{
PENGARUH PEMBERIAN EKTRAK BIJI ANGGUR (Vitis vinifera) TERHADAP KADAR SERUM ASAM URAT PADA TIKUS PUTIH JANTAN (Rattusnorvegicus strain wistar) MODEL HIPERURISEMIA
}

\author{
Novi Puspita Sari ${ }^{1}$, Isbandiyah ${ }^{2}$, Bambang Widiwanto ${ }^{3}$ \\ Fakultas Kedokteran, Universitas Muhammadiyah Malang \\ J1. Bendungan Sutami 188 A Malang, 65145
}

Email : novipuspita.fk@gmail.com

\begin{abstract}
ABSTRAK
Hiperurisemia adalah salah satu faktor yang menyebabkan angka kejadian infalmasi gout arthtritis akut, dan beberapa penyakit lain. Terjadinya hiperurisemia dapat di hambat dengan senyawa flavonoid seperti katekin dan epikatekin yang dapat menghambat enzim xantin oksidase senyawa tersebut terkandung dalam biji anggur (Vittis vinifera).penelitian ini bertujuan untuk Mengetahui pengaruh pemberian ekstrak biji anggur (Vitis vinnifera) terhadap serum asam urat dalam darah tikus putih (Rattusnorvegicus strain wistar) yang di induksi diet tinggi purin.. metode yang di gunakan merupakan Eksperimental, Post Test Only Control Group Design dilakukan selama 25 hari dengan menggunakan 28 ekor tikus putih jantan, di bagi dalam 1 kontrol positif dan 3 kelompok control perlakuan. Setiap kelompok di berikan diet tinggi purin 20mg/ekor selama 8 hari, kemudian pada kelompok perlakuan yang diberikan ekstrak biji anggur pada kelompok 1,2, dan 3 dengan dosis berturut turut 0,9, 2,7, dan 5,4 mg selama 10 hari. Analisis data menggunakan uji One way ANOVA, post hoc bonferroni, uji korelasi dan uji regresi.hasil menunjukan one way Anova didapatkan perbedaan yang signifikan $\mathrm{p}<0.001$ Hasil uji post hoc di dapatkan perbedaan yang bermakna antara tiap-tiap kelompok perlakuan, namun uji korelasi dan regresi tidak signifikan.ddaru uji statistic dapat di simpulkan pemberian ekstrak biji anggur berpengaruh, tetapi tidak berhubungan terhadap penurunan kadar serum asam urat pada tikus model hiperurisemia
\end{abstract}

Kata kunci : Asam Urat, Ekstrak Biji Anggur, Epikatekin, Katekin.

\begin{abstract}
Hyperuricemia is one of the factors that cause the incidence of inflammation in acute Gout arthritis and other disease. Hiperuricemia can be prevented by grape seed (vitis vinifera) extracts which has cathecin and epithecin that posses inhibition of xanthine oxidase ensyme Objective from this experiment to evaluate the effects of grape seed (vitis vinifera) extracts toward serum uric acid in white male rats (Rattus novergicus wistar strain)induced with high purin dietaryusing method Experimental, Post Test Only Control Group Design for 25 days by 28 white male rats were divided into 1 positive control group and 3 treatment groups. Each group were given high purin dietary $20 \mathrm{mg} /$ rats for 8 days, then the 1,2 and 3 treatment groups were given grape seed extracts at dose 0.9 , 2.7, and $5.4 \mathrm{mg}$ respectively for 10 days. Data were analized using one way ANOVA, Post hoc bonferroni and Regression test. The result of one way anova showed a significant difference $p<0.001$. Post hoc test also showed significant differences between each treatment group. but the correlation and regression test was not significant.Grape seed extract affect but not related to decreased of serum uric acid levels in white male rats model byperuricemi
\end{abstract}

Keyword : Grape seed extract, catecbin, epicatechin, uric acid 


\section{PENDAHULUAN}

Hiperurisemia adalah salah satu faktor yang menyebabkan angka kejadian inflamasi pada Gout arthritis akut (Jatuworapruk, 2014). Gout menjadi salah satu prevalensi dari penyakit yang berhubungan dengan lifestyle, sebuah penelitian di Jepang yang di lakukan tahun 2004 oleh National Livelihood menyatakan 874000 orang di rawat di rumah sakit karena gout ,apabila di bandingkan dengan tahun 1986 maka angka kejadian meningkat 3.4 kali (Kushiyama, 2014) Pada suatu studi didapatkan insiden gout $4,9 \%$ pada kadar asam urat darah $>$ $9 \mathrm{mg} / \mathrm{dL}, 0,5 \%$ pada kadar $7-8,9 \mathrm{mg} / \mathrm{dL}$, dan 0,1\% pada kadar $<7 \mathrm{mg} / \mathrm{dL}$ (Lugito,2013). Selain mengakibatkan gout arhtritis belakangan ini hiperurisemia di hubungkan dengan penyakit kardiovaskular. Data terakhir menunjukkan bahwa serum asam urat ( SAU) yang tinggi sering dikaitkan dengan sejumlah besar penyakit, SAU tinggi juga tampaknya menjadi faktor risiko independen untuk penyakit kardiovaskular dan diabetes tipe 2 (Borghi, 2014). Hiperurisemia dapat didefinisikan sebagai meningkatnya kadar serum urat dalam darah pada tingkat $>7 \mathrm{mg} / \mathrm{dL}$ (Brooks, 2010). Beberapa faktor yang menyebabkan kenaikan jumlah serum asam urat adalah jenis kelamin, ph urin, dan konsumsi diet tinggi purin seperti hasi makanan laut dan daging. Pada penelitian yang di lakukan di rumah sakit umum kota Tegal, yang subjek penilitianya 50\% merupakan pengkonsumsi makanan diet tinggi purin menunjukan bahwa tingkat asam urat lebih tinggi di bandingan dengan yang mengkonsumsi sedikit makan laut (Purwanti, 2009). Pengobatan hiperurisemia yang sering di gunakan adalah senyawa allopurinol sebagai agen yang dapat menghambat enzim Xanthin Oksidase. Namun dalam beberapa penelitian penggunaan allopurinol sebagai obat yang dapat menurunkan asam urat mempunyai beberapa efek samping.Allopurinol dapat menyebabkan intoleransi gastrointestinal seperti muntah dan diare, ruam danalergi, kejadian ini lebih sering terjadi di Asia (Dean, 2013). Di karenakan efek samping yang ada maka di gunakan terapi alternative sebagai pilihan. Salah satu bahan yang banyak di sebutkan adalah biji anggur (Vitis vinifera) yang mengandung kandungan fenol yang terdiri dari katekin dan epikatekin (Elagamey, et al, 2013). pada penelitian sebelumnya di sebutakn bahwa komponen katekin dan epikatekin yang terdapat pada ekstrak teh hijau dapat menghambat kerja enzim xantin oksidase yang dapat menurunkan kadar SUA.

Dari uraian di atas maka penelitian ini di lakukan untuk mengetahui biji anggur (Vitis vinifera) yang memngandung komponen katekin dan epikatekin sebagai penghambat enzim xanthine oksidase dalam menurunkan kadar asam urat dalam darah.

\section{BAHAN DAN METODE}

\section{Persiapan Hewan Model}

Penelitian ini dilakukan selama 25 hari dengan menggunakan 28 ekor tikus putih jantan yang kemudian dibagi menjadi 4 kelompok perlakuan. Masing-masing kelompok tersebut di adaptasikan terlebih dahulu dengan lingkungan selama 7 hari.Pada hari ke-8 sampai dengan hari ke-15 diberikan diet tinggi purin berupa jus otak kambing $20 \mathrm{mg}$ /ekor pada kelompok kontrol positifdan 3 kelompok perlakuan.

\section{Pembuatan Ekstrak Biji anggur}

Buah anggur di pisahkan dari bijinya di keringkan (di tempat teduh, suhu udara $25-30^{\circ} \mathrm{C}$ selama 1 minggu dan digilin menjadi bubuk halus. Bubuk biji anggur (0,2 gram) dimaserasi dalam $20 \mathrm{ml}$ etanol $80 \%$ suling selama 24 jam pada suhu $5{ }^{\circ} \mathrm{C}$. Filtrate yang di dapat di pekatkan dengan menggunakan rotatory evaporator selama \pm 1 jam dan dilanjutkan dengan menggunkan waterbath pada suhu 60C yang dijaga konstan sampai didapatkan bobot konstan sehingga di peroleh biji anggur ekstrak etanol. Hasil di fraksi lagi menggunakan etil asetat.

\section{Pemberian Perlakuan}

Penelitian ini dilakukan selama 25 hari dengan menggunakan 28 ekor tikus putih jantan yang kemudian dibagi menjadi 4 kelompok perlakuan.Masing-masing kelompok tersebut di adaptasikan terlebih dahulu dengan lingkungan selama 7 hari. Pada hari ke- 8 sampai dengan hari ke-15 diberikan diet tinggi purin $20 \mathrm{mg}$ / ekor pada kelompok kontrol positif dan 3 kelompok perlakuan, kemudian pada hari ke-16 sampai hari ke-25 hanya kelompok perlakuan yang diberikan ekstrak biji anggur masing-masing pada kelompok 1,2, dan 3 dengan dosis 0,9, 2,7, dan 5,4 mg sedangkan pada kelompok kontrol di beri placebo berupa lautan $\mathrm{NaCl} 0.9 \%$. 


\section{Pengambilan Darah Hewan Coba}

Setelah hewan coba teranastesi dengan baik (keadaan pingsan), hewan coba diletakkan pada meja lilin dan keempat kaki hewan coba difiksasi terhadap meja lilin dengan menggunakan jarum pentul.Dengan menggunakan gunting bedah, dilakukan pembedahan pada abdomen hingga setinggi leher. Kemudian dengan menggunakan spuit $3 \mathrm{ml}$, darah hewan coba diambil dari ventrikel kiri sebanyak $\pm 3 \mathrm{ml}$. Darah yang telah diambil sebanyak $\pm 3 \mathrm{ml}$, dilakukan sentrifuge dengan kecepatan $3000 \mathrm{rpm}$ selama 10 menit untuk mengambil supernatannya.

\section{Pemeriksaan Kadar Kolesterol Total}

a. Kadar asam urat di tetapkan berdasarkan reaksi enzimatik menggunakan reagen uric acid FS* TBHBA, perhitungan kadar asam urat dilakukan dengan cara membandingkan langsung hasil serapan larutan uji dengan asam urat standart.

Kadar asam urat serum(mg/dL) dihitung dengan menggunakan rumus :

\section{Analisis Data}

Data-data yag diperoleh dalam penelitian ini dianalisis menggunakan uji normalitas dan uji homogenitas. Apabila hasil sebaran data normal, gunakan uji One Way Anova, lalu uji Post hoc Bonferroni jika varian data sama, jika varian data tidak sama maka menggunakan uji Post hoc Tamhane kemudian dilanjutkan dengan uji Regresi Linier dan uji korelasi. Data penelitian diolah dengan menggunakan program komputer statistik SPSS 20.

\section{HASIL DAN PEMBAHASAN}

Kadar rerata asam urat tikus putih jantan (Rattus norvegicus strain wistar) pada masingmasing kelompok diperoleh dari hasil perhitungan adalah sebagai berikut :

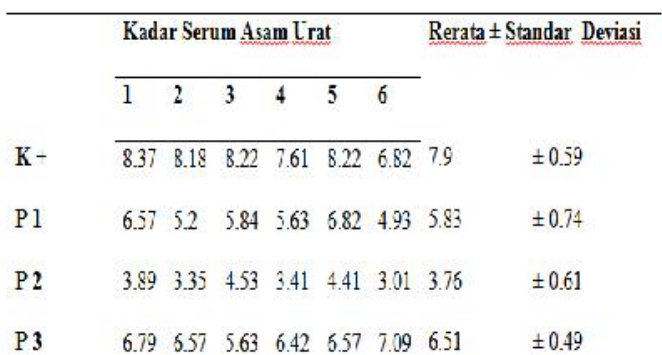

Keterangan tabel:

a. $\mathrm{K}+$ : sebagai kontrol positif di beri diet tinggi purin (jus otak kambing $20 \mathrm{mg}$ /ekor) dan placebo aqusdes $1 \mathrm{ml} /$ ekor/hari tanpa ekstrak biji anggur

b. P1 : sebagai kelompok perlakuan diet tinggi purin jus otak kambing $20 \mathrm{mg}$ /ekor) dengan ekstrak biji anggur $0,9 \mathrm{mg} /$ ekor/hari

c. P2 : sebagai kelompok perlakuan diet tinggi purin (jus otak kambing $20 \mathrm{mg} /$ ekor/hari) dengan ekstrak biji anggur 2,7 mg/ekor/ hari

d. P3 sebagai kelompok perlakuan diet tinggi purin (jus otak kambing $20 \mathrm{mg} /$ ekor/hari) dengan ekstrak biji anggur 5,4 mg/ekor/ hari

Dapat dilihat dari data tabel 5.1 di atas bahwa terdapat perbedaan rerata kadar serum asam urat tikus pada kontrol positif yang di beri diet tinggi purin dengan kelompok tikus yang di beri perlakuan ektrak biji angggur (vitis vinifera) pada masing masing dosis. Dengan demikian, berdasarkan penilaian secara deskriptif menurut rata-rata kadar asam urat pada tikus putih tersebut, maka dapat dikatakan bahwa pemberian perlakuan berupa ekstrak biji anggur(vitis vinifera) dengan dosis 0,9 mg/ekor, 2,7 mg/ekor, dan dosis 5,4 $\mathrm{mg} /$ ekor menunjukkan efek atau pengaruh yang berbeda jika dibandingkan dengan kontrol positif yang di induksi diet tinggi purin.

Pada uji One way ANOVA menunjukkan adanya pengaruh yang bermakna sehingga perlu dilakukan uji pembanding ganda (multiple comparisons) dengan uji post hoc. Karena data normal dan homogen maka digunakan post hoc Bonferroni untuk membandingkan antar kelompok kontrol dan kelompok perlakuan. Pada uji post hoc, dapat 
disimpulkan terdapat perbedaan yang signifikan antara 2 kelompok apabila nilai $\mathrm{p}<0.05$.

Dari hasil uji korelasi pearsondi dapatkan nilai signifikansi 0.216 sehingga dikatakan tidak ada hubungan yang bermakna secara statistik.

Hasil uji regresi menunjukkan tidak adanya pengaruh yang signifikan antara kelompok perlakuan yang diberikan ekstrak biji anggur kulit hitam terhadap penurunan kadar serum asam urat dilihat dari nilai sig Uji t yang $>0,05$ dengan nilai sig 0,216.Berdasarkan hasil pengamatan dan analisa statistik pada kelompok perlakuan yang di berikan ekstrak biji anggur dengan melakukan uji oneway ANOVA dan multiple comparation dengan Post Hoc bonfferoni di katakan terdapat adanya hubungan pemberian ekstrak biji anggur terhadap penurunan kadar serum asam urat dalam darah tikus putih hal ini di sebabkan kerja catechin mirip dengan allupurinol yang menghambat kerja enzim xantin oksidase sehingga pembentukan asam urat yang berlebihan dapat dihentikan. Catechin dapat pula meningkatkan pembentukan enzim urikase yang menambah asam urat menjadi alantoin yang mudah larut dalam air serta mudah diekskresikan lewat ginjal (Prabowo, 2007). Hal ini juga di dukung oleh penelitian sebelumnya dengan judul Amplification of Antioxidant Activity and Xanthine Oxidase Inbibition of Catechin by Ensymatic Polymerization diaman pada penelitian tersebut dikatakan bahwa hasil dari poly (catechin) yang mereka dapatkan merupakan salah satu inhibitor terhadap enzim xantin oxidase yang kerjanya hampir sama denga obat anti-hyperurisemia senyawa allopurinol (Motoichi et al, 2003).

Namun dalam penelitian ini apabila di lihat kekuatan hubunganya dengan uji korelasi di dapatkan hasil yang tidak signifikan dikarenakan pada dosis tertinggi dengan di berikan ekstrak biji anggur 5,4 $\mathrm{mg} /$ ekor nilai kadar serum asam urat tidak turun jika di bandingkan dengan dosis $0,9 \mathrm{mg}$ dan 2,7 mg. Hal ini dapat di pengaruhi karena dalam tubuh memiliki Total Antioxidant Capacity (TAC) dengan nilai baseline $800 \mu \mathrm{m}$ menurut penelitian Lotito \& Frei (2006). Dalam penelitian tersebut di katakana konsumsi makanan yang tingi akan flavonoid dapat meningkatkan kadar urat dalam darah Dari penelitian tersebut untuk mengetahui total antioksidan dengan metode ferric-reducing antioxidant potential (FRAP) di ukur setelah 2 jam konsumsi, didapatkan bahwa strawberry meningkatkan antioxidant capacity sebesar $21 \mu \mathrm{m}$, bayam $53 \mu \mathrm{m}$ dan anggur merah dapat meningkatkan $21 \mu \mathrm{m}$.

Dalam penelitian lainya dikatakan bahwa konsumsi teh dimana didalamnya terdapat kandungan antioksidan berupa flavonoid juga dapat meningkatkan asam urat, bisa di katakana apabila terdapat peningkatan $7 \%$ dari TAC dapat menyebabkan peningkatan asam urat sebanyak 5 sampai $7 \%$ dari rerata asam urat. Dengan demikian dari beberapa studi yang menunjukkan bahwa konsumsi makanan tinggi flavonoid dapat meningkatkan urat plasma, meskipun mekanisme yang mendasari tidak dijelaskan.(Lotito \& Frei, 2006). Selain itu pendapat ini di buktikan dalam pengolahan data apabila kelompok dengan dosis $5.4 \mathrm{mg} /$ ekor di hilangkan maka di dapatkan hasil yang signifikan Secara prosentase besarnya kontribusi yang di peroleh adalah $84,4 \%$ dengan melihat nila adjusted $\mathrm{R}$ square $=0,848$ maka dapat di katakana hasilnya bermakna.

Berdasarkan hasil yang diperoleh dari penelitian dapat disimpulkan bahwa ekstrak biji anggur anggur dapat menurunkan kadar serum asam urat pada tikus jantan yang diberikan diet tinggi purin pada dosis tertentu yaitu dosis 0,9 $\mathrm{mg} /$ ekor dan 2,7 mg/ ekor di karenakan pada dosis tertinggi 5,4 mg/ ekor penurunan kadar asam urat pada tikus jantan tidak sebaik penurunan pada dosis yang lebih rendah. Hal ini disebabkan karena kemungkinan dosisi 5,4 mg/ ekor tersebut terlalu tinggi sehingga telah malebihi total Antioxidant capacity (TAC) pada tikus.

\section{KESIMPULAN DAN SARAN}

Berdasarkan hasil penelitian dapat kesimpulan bahwa Ekstrak biji anggur pada dosis tertentu berhubungan terhadap rerata kadar serum asam urat tikus yang di induksi diet tinggi purin.Dosis optimal ekstrak biji anggur yang berpengaruh terhadap penurunan kadar serum asam urat pada tikus yang di induksi diet tinggi purin penelitian ini adalah dosis 2,7 mg/ ekor. Tidak terdapat hubungan jumlah dosis yang di berikan dengan kadar serum asam urat pada tikus

Saran yang dapat dijadikan sebagai bahan pertimbangan dan masukan untuk penelitian selanjutnya perlu dilakukan penelitian lebih lanjut mengenai seberapa besar pengaruh golongan 


\section{VOLUME 12 NOMOR 2 DESEMBER 2016}

flavonoid cathecin dan epicathekin yang dapat menghambat xantin oxidase, pengaruh ekstrak biji anggur dengan dosis yang merupakan kelipatan dari dosis terendah untuk mengetahui dosis toksik minimal yang di timbulkan sebelum dosis $5.4 \mathrm{mg} /$ ekor, serta tentang total flavonoid dalam biji anggur yang dapat mempengaruhi sehingga melebihi Total Antioksidan Capacity (TAC) dalam tikus yang mempengaruhi produksi asam urat.

\section{DAFTAR PUSTAKA}

Elagemey,A.A, Abdel Wahab,Shimma and Abdel Moghib. 2013,Comparative Study of Morphological Characteristics and Chemical Constituents for Seeds of Some Grape Table Varieties.Journal of American Science 2013;9(1)

Fahlen Mark, Mahendra Agraharkar et al.2015, Uric Acid Nephropatby.American College of Physicians, Renal Physicians Association.

Feig DI, Johnson RJ.2003, Hyperuricemia in childhood primary bypertension. Hypertension.2003,42(3):247-25 10.1161/ 01.HYP.0000085858.66548.59.

Feig DI, Soletsky B, Johnson RJ, Effect of allopurinol on blood pressure of adolescents with newly diagnosed essential hypertension: a randomized trial. Jurnal Am Med Assoc. 2008, 300 (8): 924-932. 10.1001/jama.300.8.924.

Ferruzzi. M. 2010. Bioavailability of gallic acid and catechins from grape seed polyphenol extract is improved by repeated dosing in rats: Implications for treatment in Alzheimer's. DiseaseJournal Alzheimers Dis. doi: 10.3233/JAD-2009_$\underline{1135}$

Jatuworapruk K, Srichairatanakool et al. 2014.Effects of green tea extract on serum uric acid and urate clearance in healthy individuals. Journal clinical rheumatology 2014 september ;20(6):310-3. doi: 10.1097/RHU.0000000000000148..

Nata Pratama Hardjo Lugito , 2013. Nefropati Urat, CDK-204/ vol. 40 no. 5,

Prabowo S, 2007, Pengarub Green Tea terhadap Kadar Malondialdebida dan Aktivitas Superoksida pada Artritis Ajuvan (Model Hewan untuk. Rheumatoid Artritis) Prosiding Seminar Nasional Tanaman Obat dan Obat Tradisional, Surakarta 10 - 11 Juli 2007. .Balitbang
Pribadi F.W, Ernawati DA, 2010, Efek Catechin Terhadap Kadar Asam Urat, C-Reactive Protein(Crp) Dan Malondialdebid Darah Tikus Putih (Rattus Norvegicus) Hiperurisemia, Mandala of Health,4,pp. 39-46,

Samah et al, 2012, Phenolic Compounds and Antioxidant Activity of White, Red, Black Grape Skin and White Grape Seeds, Life Science Journal,9,pp. 3464-3474 